\title{
REBORN DIGITAL I BLACK BOX - WPŁYW PROCESU ARCHIWIZACJI NA ZASÓB ARCHIWÓW WEBU
}

\section{Słowa kluczowe}

archiwizacja Webu, archiwa Webu, źródła cyfrowe, zasoby cyfrowe, historia Webu, reborn digital, black box

\section{Keywords}

Web archiving, Web archives, digital sources, digital collections, Web history, reborn digital, black box

\section{Streszczenie}

W artykule podjęte zostały rozważania nad ogólną charakterystyką zasobów znajdujących się w różnorodnych archiwach Webu. Zrozumienie problemu postawionego w ty-

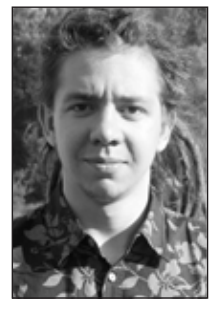

Bartłomiej Konopa, tytuł zawodowy magistra uzyskał na kierunku: archiwistyka i zarządzanie dokumentacją na Uniwersytecie Mikołaja Kopernika w Toruniu. Obecnie pracownik Archiwum Państwowego w Bydgoszczy i uczestnik studiów doktoranckich w zakresie historii na Wydziale Nauk Historycznych UMK w Toruniu. Jego zainteresowania badawcze obejmują przede wszystkim archiwizację Internetu, a także historię Torunia, źródłoznawstwo oraz teorię archiwistyki.

E-mail: bartlomiejkonopa@gmail.com

ORCID ID: 0000-0001-9843-5552 
tule wydaje się być kluczowe dla refleksji nad tym nowym rodzajem źródeł oraz wykorzystaniem ich w późniejszych badaniach. Użytkownik chcący zagłębić się w dawną Sieć musi wiedzieć, co przechowują tego rodzaju cyfrowe repozytoria i jaki jest charakter tych zbiorów. Problem ten został przedstawiony na dwóch płaszczyznach, które wynikają z dwóch etapów archiwizacji Webu - selekcji i gromadzenia. Pierwszy aspekt teoretyczny zależy przede wszystkim od gromadzenia zasobów metodą harvestingu, czyli z wykorzystaniem crawlerów. Ich możliwości oraz ograniczenia przekładają się na to, co zostanie zarchiwizowane i jaka będzie tego postać. Należy odnotować fakt, iż prowadzi to do pewnego przekształcenia zasobów Sieci, a więc po zarchiwizowaniu nie będą już one dokładnie tym, czym były wcześniej. Drugi aspekt - praktyczny jest efektem selekcji, a więc wszystkich decyzji podejmowanych przez pracowników archiwum przed rozpoczęciem i w trakcie gromadzenia. Zaliczyć można do nich m.in. określenie celu i zakresu archiwizacji oraz wybór strategii pozwalających je realizować. W tekście przedstawione zostały dwie podstawowe metody - archiwizacja masowa oraz selektywna. Znaczącym utrudnieniem dla użytkowników archiwów Webu jest brak informacji dotyczący stosowanych kryteriów selekcji lub logów crawlera. Zasoby dawnej Sieci mogą stanowić pewnego rodzaju zagadkę, ponieważ nie zawsze można wskazać, co się w nich znalazło, a co nie, i jaka była tego przyczyna.

\section{Summary}

\section{Reborn digital and black box - impact of archiving processes on holdings of Web archives}

The article contemplates general characteristics of holdings of various Web archives. Understanding the problem formed in the title seems to be crucial for reflections on this new type of sources and using it in research. A user aiming at familiarizing with the old Web must know what is stored in this type of digital repositories and what characterizes these holdings. The problem was presented on two levels, related to two stages of archiving - selection and acquisition. The first aspect, of theoretical character, depends mostly on gathering sources using the method of harvesting (with crawlers). Their capabilities and limitations result in what will be archived and in what form. It must be noted, that this can lead to a certain deformation of Web sources, thus after archiving they will not be exactly what they were before. The second aspect, of practical character, is an effect of selection, i.e. all decisions made by archives' employees before the process of gathering starts and during the process. These decisions comprise of, among others, specifying the aim and scope of archiving and choosing strategies to accomplish them. The text presents two basic strategies - mass archiving and selective archiving. An important obstacle for Web archives users is lack of information about selection criteria or crawlers' logs. Holdings of the old Web can be a kind of mystery, because not always one can describe, what is in them and what is not, and what is the reason for this state. 


\section{Wstęp}

7 Tematyka archiwizacji Webu zaczyna być dostrzegana i zyskuje coraz więk【szą popularność. Poszerza się wiedza o możliwości dotarcia do zapisów pochodzących $\mathrm{z}$ dawnych, nieistniejących lub zmienionych już witryn internetowych oraz ich szerokiego wykorzystania. Jednym z obszarów zastosowania archiwalnych zasobów sieciowych są różnorodne badania naukowe, których pierwsze przykłady można znaleźć także w Polsce ${ }^{1}$. Użytkowanie ich w tym celu, ale także każdym innym, wymaga zdawania sobie sprawy, z czym się ma do czynienia. Tak samo jak historyk opisujący przeszłe dzieje musi rozumieć kontekst powstania badanych archiwaliów, dlaczego przybrały konkretną formę oraz dlaczego zachowały się konkretne dokumenty i księgi, tak samo osoba analizująca dawny Web musi poznać analogiczne procesy. Stosując zasoby jakiegoś archiwum Sieci lub podobnego projektu, należy wiedzieć, dlaczego właśnie one zostały zarchiwizowane i dlaczego w takiej, a nie innej formie. Rozważania te można sprowadzić do problemu zawartego w tytule niniejszego artykułu.

Zawartość archiwów Webu była już przedmiotem rozważań teoretycznych, a także badań praktycznych, których celem było zrozumienie ich natury będącej konsekwencją procesu archiwizacji. Wskazać tu można na prace Nielsa Brüggera, który zajmuje się tą problematyką, a także obszarem badań określanym mianem Web history, który opiera się o zasoby pochodzące z dawnej Sieci. Jedną z nich jest publikacja Archiving Websites. General Considerations and Strategies, w której rozważa dynamikę Internetu i możliwości uchwycenia różnorodnych zmian $\mathrm{w}$ nim zachodzących ${ }^{2}$. Wymienić można również artykuł Web historiography and Internet Studies: Challenges and perspectives, gdzie autor zastanawia się nad zastosowaniem zgromadzonych zasobów Webu oraz wynikające z tego konsekwencje w badaniach nad jego przeszłościąa ${ }^{3}$. Ciekawe jest również spojrzenie Anat Ben-David i Adama Amrama zaprezentowane w tekście The Internet Archive and the socio-technical construction of historical facts. Pokazują w nim wpływ funkcjonowania procesów archiwizacji przeprowadzanej

${ }^{1}$ Np. K. Król, Z archiwów internetu: zmiany $w$ sposobie prezentacji oferty agroturystycznej, „Marketing i Rynek” 2017, nr 11, s. 19-27.

2 N. Brügger, Archiving Websites. General Considerations and Strategies, Aarhus 2005, http://cfi.au.dk/fileadmin/www.cfi.au.dk/publikationer/archiving_underside/archiving. pdf (dostęp 26.08.2019).

3 Tenże, Web historiography and Internet Studies: Challenges and perspective, „New Media Society” 2012, t. 5, nr 15, s. 752-764. DOI: 10.1177/1461444812462852. 
przez amerykańską fundację Internet Archive na możliwość poznania faktów historycznych ${ }^{4}$. Możliwości, jakie dostarczają archiwa Webu, a także metody ich wykorzystania, zaprezentował Ian Milligan w Lost in the Infinite Archive: The Promise and Pitfalls of Web Archives ${ }^{5}$.

Jedno z bardziej aktualnych omówień obecnej sytuacji w archiwizacji Sieci znaleźć można w rozdziale Web Archives z książki Remembering and Forgetting in the Digital Age autorstwa Florenta Thouvenina, Petera Hetticha, Herberta Burkerta i Ursa Gassera ${ }^{6}$ oraz w publikacji J. Nielsen Using Web Archives in Research - an Introduction ${ }^{7}$. Informacje na temat archiwów Webu oraz projektów archiwizacyjnych przytoczonych w artykule jako przykłady zostały pozyskane z ich witryn internetowych, a także z poświęconych im opracowań. Takowych doczekały się m.in. inicjatywy w Danii ${ }^{8}$, Chorwacji ${ }^{9}$ i Finlandii ${ }^{10}$.

Przytoczona powyżej literatura, a także inne opracowania oraz wyniki badań posłużą do rozważań nad zagadnieniem zawartym w tytule artykułu. Do problemu wpływu procesu archiwizacji na zasób archiwów Webu można podejść w sposób dwojaki, co będzie stanowiło główne ramy niniejszego opracowania. Po pierwsze, zjawisko archiwalnego Webu rozważać można w sposób ogólny i teoretyczny, jako efekt procesu gromadzenia i rozwiązań technologicznych mających na niego duży wpływ. Od pracy crawlerów, wyspecjalizowanych robotów internetowych, w znacznym stopniu zależy, co i w jakiej postaci zostanie

${ }^{4}$ A. Ben-David, A. Amram, The Internet Archive and the socio-technical construction of historical facts, „Internet Histories. Digital Technology, Culture and Society” 2018, t. 2, nr 1-2, s. 179-201. DOI: 10.1080/24701475.2018.1455412.

5 I. Milligan, Lost in the Infinite Archive: The Promise and Pitfalls of Web Archives, „International Journal of Humanities and Arts Computing” 2016, t. 10, nr 1, s. 78-94. DOI: 10.3366/ijhac.2016.0161.

${ }^{6}$ F. Thouvenin, P. Hettich, H. Burkert, U. Gasser, Web Archives, [w:] Remembering and Forgetting in the Digital Age, S Cham 2018, s. 81-101. DOI: 10.1007/978-3-319-90230-2.

7 J. Nielsen, Using Web Archives in Research: an Introduction, Aarhus 2016. http:// www.netlab.dk/wp-content/uploads/2016/10/Nielsen_Using_Web_Archives_in_Research.pdf (dostęp 26.08.2019)

8 S. Schostag, E. Fønss-Jørgensen, Webarchiving: Legal Deposit of Internet in Denmark. A Curatorial Perspective, „Microform \& Digitization Review” 2012, t. 41, nr 3-4, 2012, s. 110-120. DOI: $10.1515 / \mathrm{mir}-2012-0018$.

9 K. Holub, I. Rudomino, A decade of web archiving in the National and University Library in Zagreb, materiały z konferencji IFLA WLIC 2015, Kapsztad, 11-20 sierpnia 2015, s. 1-12. http://library.ifla.org/1092/1/090-holub-en.pdf (dostęp 26.08.2019).

${ }^{10}$ E.-P. Keskitalo, Web Archiving in Finland: memorandum for the members of the CDNL, 2010. http://www.doria.fi/bitstream/handle/10024/67051/webarchivingfinland_cdnl. pdf (dostęp 26.08.2019). 
zachowane. Po drugie, zarchiwizowaną Sieć rozpatrywać można jako wynik strategicznych decyzji związanych z selekcją, podejmowanych $\mathrm{w}$ ramach poszczególnych projektów, a więc przez odpowiedzialne za nie osoby. Każda taka inicjatywa w zależności od swoich potrzeb, a także ograniczeń wynikających z przepisów prawa oraz posiadanych zasobów ludzkich, finansowych i technologicznych, dostosowuje swoją strategię, która określa, jakie zasoby będą (i jakie nie będą) archiwizowane. Rozważając kwestie związane z selekcją, warto przyjrzeć się kilku przykładom obecnie działających archiwów, aby pokazać różnorodność w ich funkcjonowaniu, ale także występujące podobieństwa. Umożliwi to pokazanie praktycznej realizacji omawianych zagadnień.

Zatem co takiego stanowi zawartość archiwów Webu? Najprostszą odpowiedzią na to pytanie, która nasuwa się w pierwszej kolejności, jest stwierdzenie, że można znaleźć w nich zasoby pochodzące z dawnej, nieistniejącej już Sieci. Można w nich uzyskać dostęp do domen narodowych, a także grup witryn powiązanych ze sobą tematycznie (np. witryny kandydatów w wyborach, portale informacyjne, blogi itp.). Pozwalają one na korzystanie z poszczególnych witryn internetowych, pojedynczych stron, poszczególnych elementów, np. grafiki czy nagrania wideo, a także $\mathrm{z}$ łączących poszczególne elementy hiperłączy ${ }^{11}$. Za główny „produkt” archiwizacji należy jednak uznać archiwalne wersje stron WWW, które składają się w znaczniej części z tekstów w postaci plików HTML, oprócz których pojawiają się inne formaty, a także pliki PDF, nagrania dźwiękowe, zdjęcia, grafiki, pliki audio i wideo oraz inne elementy multimedialne ${ }^{12}$. Takie zdefiniowanie zasobów archiwów jest jednak zbyt proste i nie odnosi się do problemów przedstawionych we wstępie artykułu. Aby móc lepiej poznać istotę tych źródeł, należy najpierw zdefiniować i zrozumieć proces odpowiedzialny za ich powstawanie.

Archiwizacja Webu może być rozumiana w bardzo szeroki sposób, jako każde świadome i celowe zachowywanie zasobów Sieci ${ }^{13}$. Takie definiowanie tego zjawiska obejmuje co prawda działalność archiwów, jednak wykracza także daleko poza nie. Poprzez archiwa Webu rozumie się tutaj instytucje lub projekty, które - wykonując poszczególne funkcje - dążą do zachowania zasobów pochodzących z Webu i następnie udostępnienia ich zainteresowanym. Ich

11 Więcej o różnych poziomach analizowania Webu zob. N. Brügger, When the present web is later the past: web historiography, digital history and internet studies, „Historical Social Research" 2012, t. 37, nr 4, s. 111-114. DOI: 10.12759/hsr.37.2012.4.102-117.

12 Tenże, Web historiography, s. 756-757.

${ }^{13}$ Tenże, Web Archiving - Between Past, Present, and Future, [w:] Handbook of Internet Studies, red. M. Consalvo, C. Ess, Oxford 2011, s. 25. 
aktywność jest w miarę możliwości regularna i nastawiona na długie trwanie ${ }^{14}$. Wspomniane funkcje składają się na proces archiwizacji Sieci, pojmowany w jego węższym znaczeniu jako czynności związane z selekcją, gromadzeniem, przechowywaniem, zachowywaniem i zarządzaniem dostępem do zrzutów (ang. snapshots) zasobów Sieci w czasie ${ }^{15}$. Ma tu również zastosowanie pojęcie makroarchiwizacji stworzone przez Nielsa Brüggera, która przeprowadzana jest na dużą skalę, przez instytucję posiadającą odpowiednie zaplecze sprzętowe i kadrowe, a jej cel stanowi zabezpieczenie dziedzictwa kulturowego ${ }^{16}$. Jak już wcześniej zaznaczono, na zawartość archiwów Webu wpływ mają właśnie selekcja oraz gromadzenie zasobów.

\section{Aspekt teoretyczny - wpływ gromadzenia}

Rozpoczęcie rozważań od aspektu teoretycznego wymaga zwrócenia uwagi na kwestię gromadzenia zasobów Sieci. Istnieje parę rozwiązań pozwalających na ich pozyskiwanie, jednak najczęściej wykorzystywaną metodą jest pobieranie archiwalnych kopii od strony klienta, określaną często jako „harvesting”. W jej trakcie wykorzystuje się specjalne oprogramowanie w postaci robotów internetowych nazywanych crawlerami lub harvesterami. Ich działanie polega na poruszaniu się po hiperłączach od witryny do witryny wedle reguł ustalonych uprzednio przez pracowników archiwum, takich jak zakres domen do archiwizacji, jej głębokość, rozmiar gromadzonych elementów czy podążanie za linkami zewnętrznymi ${ }^{17}$. Działanie crawlera rozpoczyna się od startowej listy adresów internetowych, tzw. seed list, która jest efektem przeprowadzonej wcześniej selekcji ${ }^{18}$.

Przedstawiona powyżej metoda archiwizacji pozwala na dość łatwe archiwizowanie dużych ilości zasobów Sieci, nie jest jednak rozwiązaniem idealnym,

${ }^{14}$ F. Thouvenin, P. Hettich, H. Burkert, U. Gasser, dz. cyt., s. 85; B. Konopa, Archiwa Internetu jako nowe bazy źródłowe, „Archiwa - Kancelarie - Zbiory”, 2018, nr 9 (11), s. 56. DOI: 10.12775/AKZ.2018.003.

15 ISO/TR 14873:2013 Information and documentation - Statistics and Quality Indicators for Web Archiving.

${ }^{16}$ N. Brügger, Archiving Websites, s. 11.

17 J. Nielsen, dz. cyt., s. 11-14.

18 E. Summers, R. Punzalan, Bots, Seeds and People: Web Archives as Infrastructure, [w:] Proceedings of the 2017 ACM Conference on Computer Supported Cooperative Work and Social Computing - CSCW'17, Portland 2017, s. 2. DOI: 10.1145/2998181.2998345. 
które pozwala na zabezpieczenie wszystkiego, co się w niej pojawiło. Już sam przedmiot archiwizacji, jakim są witryny internetowe i inne zasoby Webu, przysparza znacznych problemów. Wynikają one z ich ciągle zwiększających się rozmiarów oraz nieustannie zachodzących $\mathrm{w}$ nich zmian. W przeciwieństwie do książek lub tradycyjnych akt, które po odłożeniu na półkę w magazynie zasadniczo nie ulegają zmianom, witryna, której utworzono archiwalną kopię, może ulec całkowitemu przeobrażeniu tuż po tym fakcie ${ }^{19}$. Chcąc zachować idealny obraz dawnego Webu, należałoby monitorować każdą witrynę i wykonywać na bieżąco jej zrzuty. Obecnie jest to niemożliwe, ponieważ wymagałoby to mocy obliczeniowej oraz przestrzeni dyskowej przekraczającej współczesne możliwości techniczne ${ }^{20}$. Rozważyć należy, czy archiwizacja na taką skalę będzie konieczna, ponieważ archiwiści i historycy już dawno zauważyli, że nie trzeba zachowywać każdego pojedynczego dokumentu, aby móc poznać przeszłość.

Archiwizacja przy użyciu crawlerów ma też kilka istotnych ograniczeń, które mogą utrudnić lub uniemożliwić pozyskanie części zasobów Webu. Wynikają one zarówno z niedoskonałości narzędzia, jakim są roboty internetowe, a także z samego funkcjonowania Sieci. Oprogramowanie służące do archiwizacji jest cały czas rozwijane, jednak zarówno dla jego dawnych wersji, jak i tych najbardziej aktualnych, pewne rodzaje materiałów mogą stanowić przeszkody. Najczęściej zalicza się do nich elementy stron przygotowanych w JavaScript, formacie Flash, zawartość generowana dynamicznie (może ona stanowić „pułapki" dla robotów, które mogą zaburzyć ich działanie), streamingi na żywo, media społecznościowe ${ }^{21}$. Problem mogą stanowić dla nich również wszelkiego rodzaju „nietrywialne interakcje”, takie jak np. wpisane loginu i hasła lub kodu captcha ${ }^{22}$. Poza zasięgiem crawlerów znajduje się również Ukryty Internet, a więc wszelkiego rodzaju zasoby nieindeksowane przez przeglądarki, m.in. ze względu na brak prowadzących do nich linków ${ }^{23}$. Ponadto można zablokować im dostęp do jakiejś witryny poprzez Robots Exclusion Protocol (odpowiednio

19 J. Nielsen, dz. cyt., s. 7-8.

${ }^{20}$ ISO/TR 14873:2013, s. 8; M. Spaniol, D. Denev, A. Mazeika, G. Weikum, P. Senellart, Data quality in web archiving, [w:] WICOW '09 Proceedings of the 3rd workshop on Information credibility on the web, Nowy Jork 2009, s. 20. DOI: 10.1145/1526993.1526999.

${ }^{21}$ ISO/TR 14873:2013, s. 8-9; J. Nielsen, dz. cyt., s. 15-16.

22 J. Masanes, Web Archiving Methods and Approaches: A Comparative Study, „Library Trends" 2005, t. 54, nr 1, s. 74. DOI: 10.1353/lib.2006.0005.

${ }^{23}$ Więcej o Ukrytym Internecie: N. Pamuła-Cieślak, Ukryty Internet - nowe podejście, [w:] Oblicza przestrzeni informacyjnej $w$ dobie Web 2.0, red. K. Domańska, E. Głowacka, P. Marzec, Bydgoszcz 2016, s. 35-48. 
konfigurując specjalny plik robots.txt), za pomocą którego administrator może zadecydować, jakie roboty i w jakim zakresie mogą ją odwiedzać. W końcu crawler może wejść na adres URL, który jest w danym momencie nieaktywny, np. z powodu awarii serwera, co także uniemożliwi archiwizację zasobów, które powinny się pod nim znajdować ${ }^{24}$.

Inny, znaczący problem, który wynika z omawianego sposobu gromadzenia zasobów Sieci, to wewnętrzna niekoherencja archiwalnych kopii witryn. Może ona występować w dwojaki sposób. Pierwszy wariant występuje, gdy witryna ma osadzony element pobierający zawartość spoza niej, który w archiwum może działać niepoprawnie. Zawartość ta może nie zniknąć z Sieci, a więc na jej miejscu zostanie puste pole, lub może ulec zmianie i wyświetlona zostanie jej wersja funkcjonująca w momencie korzystania z archiwum. Jako przykład można przytoczyć za J. Nielsen wtyczkę z prognozą pogody lub okienko Facebooka zamieszczane na witrynach, które będą wyświetlać najnowsze dane zamiast tych z przeszłości ${ }^{25}$. Drugim możliwym rodzajem niekoherencji jest rozbieżność czasowa pomiędzy archiwizacjami poszczególnych podstron w obrębie jednej domeny. Wynika to z faktu, iż crawler nie wykonuje kopii całej witryny w jednym momencie (choć byłoby to rozwiązanie idealne), ponieważ mogłoby to obciążyć serwer, na którym jest ona zamieszczona, a proces archiwizacji Sieci nie powinien przeszkadzać w jej codziennym funkcjonowaniu. Może to jednak skutkować tym, że w trakcie pracy robota poszczególne elementy mogą ulec zmianie. Powstała w ten sposób archiwalna kopia witryny nie będzie jej idealnym odwzorowaniem i może składać się ze stron funkcjonujących w różnych momentach, co może być niekorzystne dla badania pewnych zjawisk ${ }^{26}$.

W tym momencie można podsumować wpływ gromadzenia zasobów Sieci za pomocą robotów na późniejszą zawartość archiwów Webu. Kopie wykonane przez crawlery nie oddają dokładnie dawnego wyglądu witryn internetowych, pewnych ich elementów może brakować, a część nie będzie działać poprawnie. Zarchiwizowana witryna nie jest już tym, czym była wcześniej, kiedy funkcjonowała w „żywej” Sieci i powinna być traktowana raczej jako jej rekonstrukcja. Proces archiwizacji w pewien sposób ją przetworzył, czego efektem jest specyficzny rodzaj źródła. Najogólniej materiały cyfrowe dzieli się na:

- zdigitalizowane - pierwotnie analogowe, które przeniesiono do formy cyfrowej, np. przez skanowanie,

\footnotetext{
24 J. Nielsen, dz. cyt., s. 15-16.

25 Tamże, s. 15.

${ }^{26}$ M. Spaniol, D. Denev, A. Mazeika, G. Weikum, P. Senellart, dz. cyt., s. 19-21.
} 
- $\quad$ natywnie cyfrowe (born digital) - powstałe w formie cyfrowej i w związku $\mathrm{z}$ tym nie posiadają analogowego oryginału,

- odrodzone cyfrowo (reborn digital) - źródła cyfrowe (zdigitalizowane oraz natywnie cyfrowe), które zostały zgromadzone i zachowane w procesie, który je przemienił.

Na podstawie tego, co zostało wcześniej wspomniane, zasoby archiwalnego Webu można zaliczyć do trzeciej grupy ${ }^{27}$. Przydatne może być potraktowanie ich jako sposobu zachowania obiektów dynamicznych, do których bez wątpienia można zaliczyć Sieć. Wymienić można trzy metody, które to umożliwiają:

- dokumentację - nie zabezpiecza obiektu bezpośrednio, jednak pozwala na zachowanie informacji na jego temat w dowolnej formie (np. w postaci notatek, zdjęć lub nagrań audio i video),

- zabytek (ang. monument) - zabezpieczenie obiektu poprzez wydobycie go z obiegu, w którym funkcjonował i zachowanie go niezmienionego,

- odbitkę (ang. imprint) - zabezpieczenie obiektu poprzez przeniesienie go do innego medium, które umożliwi jego zachowanie (np. nagranie audycji radiowej).

N. Brügger, we wspomnianej we wstępie pracy, uznaje produkty archiwizacji Webu jako dokumentację, jednak odnosi się do zdefiniowanej przez niego mikroarchiwizacji, która dotyczy gromadzenia materiałów przez badaczy na ich własne potrzeby. W przypadku działalności archiwów Webu właściwsze wydaje się określenie ich zasobów jako niedoskonałych odbitek tego, co mogło być kiedyś dostępne online ${ }^{28}$.

\section{Aspekt praktyczny - wpływ selekcji}

Faktyczna zawartość archiwów Sieci, a więc to, jakie konkretnie witryny się w nich znalazły, a także jakie nie, zależy od subiektywnych decyzji podejmowanych przez człowieka $\mathrm{w}$ trakcie archiwizacji. Inicjatorzy każdego takiego projektu muszą stwierdzić, jakie zasoby chcą zachować, wybrać odpowiednie strategie oraz oprogramowanie, określić kryteria selekcji oraz parametry pracy crawlera $^{29}$. Pomimo rozróżniania automatycznego gromadzenia zasobów przez

\footnotetext{
27 N. Brügger, When the present Web, s. 103-104, 108-109.

28 Tenże, Archiving Websites, s. 15-19, 29-31.

29 Tenże, When the present Web, s. 108-109.
} 
roboty (tzw. gromadzenia masowego) od ręcznego wybierania ich przez człowieka (tzw. gromadzenia selektywnego) można zgodzić się z J. Masanès, że archiwizacja zawsze jest $\mathrm{w}$ jakimś stopniu selektywna ze względu na szereg decyzji podejmowanych $w$ jej trakcie ${ }^{30}$.

Oprócz omówionego w poprzedniej części artykułu gromadzenia zasobów Sieci, wpływ na to, co znajduje się w archiwach Webu, ma selekcja, a więc wszelkie czynności związane z wyborem materiałów do zachowania. Za jej początek można uznać ustalenie zakresu działalności danego projektu, a więc tego, jaki wycinek Sieci będzie go interesował. Jest to podstawowa decyzja dla archiwum, wskazująca na to, co jego organizatorzy chcą zachować i czego można poszukiwać w ich zasobie. Tego rodzaju inicjatywy mogą objąć swoim zasięgiem Web związany z jakimś narodem, konkretnym zagadnieniem, zjawiskiem, tematyką lub wydarzeniem ${ }^{31}$.

Wśród funkcjonujących obecnie na świecie archiwów Sieci, zgodnie z tym, co stwierdzono powyżej, można wskazać projekty o różnych zakresach gromadzenia. Najbardziej oczywistym przykładem jest działająca od 1996 r. amerykańska fundacja Internet Archive, która dąży do zabezpieczenia jak największej ilości zasobów całego $\mathrm{Webu}^{32}$. Podobny charakter ma również Common Crawl ${ }^{33}$. Kolejną kategorię mogą stanowić projekty o charakterze narodowym. Ze względu na przepisy prawa w poszczególnych krajach, mogą ograniczać się one do gromadzenia wybranych witryn powiązanych z danym narodem, na kopiowanie których mają zgodę, lub swoją działalnością mogą ponadto obejmować krajową domenę najwyższego poziomu. Do pierwszej grupy zaliczyć można japoński Web Archiving Project ${ }^{34}$, holenderski KB Webarchief van Nederland ${ }^{35}$ czy baskijski Ondarenet ${ }^{36}$. Wśród projektów, które mogą gromadzić domenę krajową,

30 J. Masanès, Selection for Web Archives, [w:] Web Archiving, red. J. Masanès, Berlin-Heidelberg 2006, s. 76.

31 J. Nilsen, dz. cyt., s. 21-22.

32 About the Internet Archive, https://archive.org/about/ (dostęp 26.08.2019)

${ }^{33}$ In a nutshell, Here's Who We Are, https://commoncrawl.org/about/ (dostęp 26.08. 2019).

34 Archiving Internet Information, https://www.ndl.go.jp/en/collect/internet/index. html (dostęp 26.08.2019).

35 Selection [online], https://www.kb.nl/en/organisation/research-expertise/longterm-usability-of-digital-resources/web-archiving/selection (dostęp 26.08.2019).

${ }^{36}$ F.P. Vernalte, S.M. Maci, Capturing the Basque Web, matariały z konferencji LIDA 2009, Dubrownik i Zadar (Chorwacja), 25-29 maja 2009, s. 8-9. http://eprints.rclis. org/13164/1/EN_Lida_paper_Ondarenet_APA.pdf (dostęp 26.08.2019). 
znajduje się między innymi brytyjski UK Web Archive ${ }^{37}$, duński Netarkivet ${ }^{38}$, kataloński PADICAT ${ }^{39}$ czy singapurski Web Archive Singapore ${ }^{40}$. Jak można zauważyć, trend powoływania narodowych archiwów Webu objął liczne państwa Europy, a także innych kontynentów. Liczba takich przedsięwzięć wzrasta i są one wciąż rozwijane, a jako dowód tego zjawiska wskazać można prace nad nowym projektem prowadzone w Królewskiej Bibliotece Belgii ${ }^{41}$.

Oprócz archiwów o tak szerokim i ogólnym zakresie wskazać można na mniejsze projekty gromadzące materiały w oparciu o bardziej szczegółowe kryteria, głównie o charakterze rzeczowym. Takie inicjatywy są liczne oraz bardzo zróżnicowane i na potrzeby tego artykułu zostaną przedstawione w obrębie przykładowych grup. Jednym z możliwych do wyróżnienia typów są archiwa zainteresowane materiałami powiązanymi z rządami lub administracją państwową. Wymienić można tu chociażby działania prowadzone przez Archiwa Narodowe Wielkiej Brytanii UK Government Web Archive ${ }^{42}$ lub australijskie Australian Government Web Archive (w 2019 r. zostało włączone do Australian Web Archive) ${ }^{43}$. Wskazać można także na projekt Congressional \& Federal Government Web Harvests, za który odpowiedzialna jest amerykańska agencja National Archives and Records Administration ${ }^{44}$. Zaliczyć można do nich również takie inicjatywy, jak End of Term Web Archive ${ }^{45}$ oraz CyberCemetery ${ }^{46}$, a także EU Web Archive ${ }^{47}$.

37 Collection guides. UK Web Archive, https://www.bl.uk/collection-guides/uk-webarchive (dostęp 26.08.2019).

38 S. Schostag, E. Fønss-Jørgensen, dz. cyt., s. 110-111.

${ }^{39}$ Mission and objectives, https://www.padicat.cat/en/about-us/what-padicat/mission-and-objectives (dostęp 26.08.2019).

40 FREQUENTLY ASKED QUESTIONS, http://eresources.nlb.gov.sg/webarchives/faq (dostęp 26.08.2019).

${ }^{41}$ F. Geereart, S. Soyez, The first steps towards a Belgian web archive: a federal strategy, materiały z IIPC Web Archiving Conference 2019, Zagrzeb, 6-7 czerwca 2019, http:// netpreserve.org/ga2019/wp-content/uploads/2019/07/IIPCWAC2019-FRIEDEL_GEERAERT_SEBASTIEN_SOYEZ-The_first_steps_towards_a_Belgian_web_archive-a_federal_ strategy.pdf (dostęp 26.08.2019).

${ }^{42}$ UK Government Web Archive, http://www.nationalarchives.gov.uk/webarchive/ (dostęp 26.08.2019).

${ }^{43}$ Archived websites (1996 e now), https://trove.nla.gov.au/website (dostęp 26.08. 2019).

${ }^{44}$ Congrssional \& Federal Government Web Harvests, https://www.webharvest.gov/ (dostęp 26.08.2019).

${ }^{45}$ The End of Term Web Archive, http://eotarchive.cdlib.org/ (dostęp 26.08.2019).

46 CyberCemetery, https://govinfo.library.unt.edu/ (dostęp 26.08.2019).

47 About the web archive of the EU institutions, https://www.eui.eu/Research/HistoricalArchivesOfEU/WebsitesArchivesofEUInstitutions (dostęp 26.08.2019). 
Wskazane archiwa gromadzą witryny i inne zasoby Webu powiązane z różnymi instytucjami państwowymi różnego szczebla, a także politykami sprawującymi najważniejsze stanowiska.

Inną kategorią możliwą do wydzielenia są projekty gromadzące zasoby Sieci na potrzeby badań naukowych. Ich organizatorami są przeważnie biblioteki uniwersyteckie. Przywołać można tu Digital Archive for Chinese Studies prowadzone równocześnie na uniwersytetach w Heildelbergu ${ }^{48}$ i Leiden ${ }^{49}$, które gromadzą materiały mogące być użyteczne dla sinologów. Wiele inicjatyw tego rodzaju korzysta obecnie z przygotowanej przez Internet Archive platformy Archive-It, która pozwala subskrybentom na tworzenie własnych zbiorów archiwalnego Webu bez przygotowywania specjalistycznego zaplecza ${ }^{50}$. Za przykład posłużyć mogą Latin American Web Archiving Project prowadzony na Uniwersytecie Teksasu w Austin ${ }^{51}$ lub kolekcje budowane przez bibliotekę Uniwersytetu Columbia ${ }^{52}$ czy oksfordzką Bibliotekę Bodlejańską ${ }^{53}$. Materiały gromadzone są często według ściśle określonego zagadnienia lub problemu, ważnych społecznie zjawisk lub wydarzeń - tak, aby umożliwić ich wykorzystanie w nauce. Podobny charakter ma działalność na tym polu prowadzona przez Bibliotekę Kongresu USA ${ }^{54}$. Ponadto częstą praktyką jest archiwizowanie witryn powiązanych z daną uczelnią, co można dostrzec m.in. na Uniwersytecie Harvarda ${ }^{55}$ oraz Massachusetts Institute of Technology ${ }^{56}$.

Kolejnym elementem związanym z selekcją jest wybór strategii archiwizacji, która pozwoli realizować obrany cel. Dwie podstawowe strategie to wspomniane

${ }^{48}$ About DACHS, https://www.zo.uni-heidelberg.de/boa/digital_resources/dachs/ about_en.html (dostęp 26.08.2019).

${ }^{49}$ Digital Archive for Chinese Studies. Leiden Division, https://projects.zo.uni-heidelberg.de/archive2/DACHS_Leiden/ (dostęp 26.08.2019).

${ }_{50}$ About Archive-It, https://archive-it.org/blog/learn-more/ (dostęp 26.08.2019).

${ }^{51}$ Latin American Web Archiving Project, http://lanic.utexas.edu/project/archives/ (dostęp 26.08.2019).

52 Web Archives at Columbia, https://library.columbia.edu/collections/web-archives. html (dostęp 26.08.2019).

${ }^{53}$ Bodleian Libraries' Web Archive, https://www.bodleian.ox.ac.uk/beam/webarchive (dostęp 26.08.2019).

${ }^{54}$ Archived Web Sites, https://www.loc.gov/programs/web-archiving/archivedweb-sites/?fa = partof:Digital+Collections\%7Coriginal-format:archived + web + site\&sp =1 (dostęp 26.08.2019).

55 Kolekcje przygotowane przez Harvard University Archives: https://archive-it.org/ organizations/935 (dostęp 26.08.2019).

${ }^{56}$ Kolekcje przygotowane przez MIT Libraries w Archive-It: https://archive-it.org/ home/MIT (dostęp 26.08.2019). 
wyżej gromadzenie masowe i selektywne, które występują w różnych wariantach i często są ze sobą łączone ${ }^{57}$.

Gromadzenie masowe (ang. bulk harvesting), jak można wywnioskować z jego nazwy, służy przede wszystkim do pozyskiwania dużych zbiorów danych, takich jak np. domena narodowa. Pomimo tego że archiwizacja tą metodą trwa niekiedy nawet parę tygodni, to nie wymaga dużego nakładu pracy człowieka. Wystarczy, aby kontrolować, czy crawler funkcjonuje prawidłowo, nie uległ awarii lub nie wpadł w pułapkę. Jest to proces w znacznej części zautomatyzowany, łącznie z kontrolą jakości wykonanych w jego trakcie zrzutów. Powoduje to jednak stopniową utratę kontroli nad nim, a w efekcie nad tym, co dokładnie trafi do archiwum i jaka będzie tego jakość. Ponadto, powstałe w ten sposób zbiory dawnego Webu nie są logicznie ustrukturyzowane i opatrzone tylko najbardziej podstawowymi metadanymi ${ }^{58}$.

Drugą, zasadniczą strategią stosowaną często w archiwizacji Webu jest gromadzenie selektywne (ang. selective harvesting). Stanowi ona niejako przeciwieństwo gromadzenia masowego, często służy jako jego uzupełnienie, ale również funkcjonuje samodzielnie. Stosując archiwizację selektywną, gromadzi się zdecydowanie mniej zasobów, jednak można to wykonywać częściej, co jest zaletą przy archiwizowaniu ważnych witryn, które ulegają bezustannym zmianom, takim jak portale informacyjne. Strategia ta pozwala na zachowanie większej kontroli nad tym, co i kiedy jest archiwizowane, a także pozwala na dokładniejsze wykonywanie kontroli jakości przez człowieka. Inną korzyścią jej stosowania jest tworzenie katalogów tematycznych oraz kolekcji, a także opatrzenie archiwalnych witryn bardziej rozbudowanymi metadanymi. To wszystko wymaga jednak większego zaangażowania archiwistów, co następnie przekłada się na wykorzystywanie ją na małą skalę ${ }^{59}$.

W ramach strategii selektywnej można wskazać dwa różne podejścia do gromadzenia zasobów. Pierwszym z nich jest archiwizacja tematyczna, w ramach której dobiera się witryny skupione wokół określonego zagadnienia lub przedmiotu w oparciu o określone kryteria. Drugi wariant to tzw. event harvesting polegający na archiwizowaniu zasobów Webu dotyczących ważnych wydarzeń, zarówno zaplanowanych (np. wybory lub igrzyska olimpijskie) oraz nagłych (np. katastrofy naturalne, zamachy terrorystyczne, rozruchy społeczne itp. ${ }^{60}$.

\footnotetext{
57 J. Nilsen, dz. cyt., s. 21-22.

58 ISO/TR 14873:2013, s. 9.

59 Tamże, s. 8.

60 J. Nielsen, dz. cyt., 21-22.
} 
Jak wygląda realizacja przedstawionych powyżej strategii archiwizacji w praktyce? Najbardziej rozbudowane działania prowadzi Internet Archive, które oprócz masowego gromadzenia zasobów pochodzących z całego WWW współpracuje z innymi instytucjami i organizacjami chcącymi zachować jakiś fragment Sieci, m.in. z fundacją Wikimedia ${ }^{61}$ oraz kolektywem ArchiveTeam ${ }^{62}$. Szczegółowe omówienie poczynań tego największego archiwum webowego może wymagać osobnego opracowania.

Mniej skomplikowane jest funkcjonowanie projektów narodowych, które w zależności od sytuacji prawnej łączą obie strategie lub archiwizują wyłącznie w sposób selektywny. Krajowe archiwa, które mają tę możliwość, w sposób masowy gromadzą całe domeny narodowe (m.in. we wspomnianych wcześniej Wielkiej Brytanii, Danii i Singapurze), a także domeny powiązane z terytoriami zależnymi (np. Biblioteka Narodowa Finlandii gromadzi domenę .ax należącą do Wysp Alandzkich ${ }^{63}$ ). Przykład duńskiego Netarkivet pokazuje, że lista adresów pochodzących z wybranej domeny może zostać poszerzona o witryny spoza niej, o ile odpowiadają one profilowi archiwum ${ }^{64}$. Archiwizację masową przeprowadza się przeważnie raz do roku i trwa przez jakiś czas, wskutek czego uzyskany obraz Sieci może posiadać znaczne przerwy. Ponieważ Internet charakteryzuje się dużą dynamiką, może to doprowadzić do utraty pewnych ważnych informacji.

Rozwiązaniem pozwalającym na choć częściowe wypełnienie tych luk jest zastosowanie strategii selektywnej. Opierają na niej swe działania także archiwa narodowe, które nie mają możliwości archiwizowania całej domeny, a także mniejsze inicjatywy skupione na konkretnych zagadnieniach. Niezależnie od tego, jej przebieg w poszczególnych projektach jest do siebie zbliżony i zgodny z przedstawionym wcześniej opisem. Istotny element, niezbędny w przeprowadzaniu selekcji, stanowią kryteria, które niestety często publikowane są $\mathrm{w}$ uproszczonej wersji. W przypadku duńskiego archiwum mamy wyłącznie informację o rodzajach witryn, którymi są one objęte wraz z częstotliwością ich gromadzenia ${ }^{65}$, natomiast o zasadach stosowanych w projektach fińskim ${ }^{66}$

${ }^{61}$ Zasoby zarchiwizowane we współpracy z Wikimedia Foundation: https://archive. org/details/wikimediadownloads?tab=about (dostęp 26.08.2019).

${ }^{62}$ Zasoby zarchiwizowane we współpracy z ArchiveTeam: https://archive.org/details/ archiveteam?tab=about (dostęp 26.08.2019).

63 E.-P. Keskitalo, dz. cyt., s. 10.

64 S. Schostag, E. Fønss-Jørgensen, dz. cyt., s. 110-111.

${ }^{65}$ Selektive høstninger, http://netarkivet.dk/om-netarkivet/selektive-hostninger_ 2016/ (dostęp 26.08.2019).

66 E.-P. Keskitalo, dz. cyt., s. 11. 
i chorwackim ${ }^{67}$ można dowiedzieć się więcej. Wykorzystują one takie kryteria, jak rodzaj witryn (np. blogi, serwisy z informacjami), ich tematyka, powiązanie z istotnymi wydarzeniami, struktura, zawartość, autorstwo, format czy unikatowość. Zasoby zgromadzone przy wykorzystaniu strategii selektywnej przeważnie są ustrukturyzowane i podzielone na kategorie lub kolekcje. Kategorie mają bardziej ogólny charakter i tworzone są głównie według tematów (np. media, prawo, polityka), co zauważyć można m.in. w archiwach Webu w Chorwacji ${ }^{68}$, Kraju Basków ${ }^{69}$ czy Australii ${ }^{70}$. Możliwe jest inne podejście, np. zastosowany w japońskim Web Archiving Project podział według instytucji ${ }^{71}$ lub w rozbudowany schemat Digital Archive for Chinese Studies ${ }^{72}$. Drugą formą organizacji archiwalnych zasobów WWW są kolekcje, które są zdecydowanie mniejsze, bardziej skonkretyzowane i skupione na szczegółowym zagadnieniu lub wydarzeniu. Częstą praktyką jest tworzenie dość jednolitych kolekcji poświęconych wyborom (można je znaleźć m.in. w archiwach Katalonii ${ }^{73}$, Chorwacji ${ }^{74}$ lub w zbiorach Biblioteki Kongresu USA ${ }^{75}$ ), jednak bardziej rozmaite przykłady zobaczyć można w UK Web Archive ${ }^{76}$ lub Web Archive Singapore ${ }^{77}$.

Przeprowadzenie archiwizacji, tak jak to zostało wcześniej zaznaczone, wymaga podjęcia wielu decyzji, które rzutują na to co zostanie zachowane a co nie. Takie informacje jak kryteria selekcji, ustawienia crawlera oraz logi dokumentujące jego pracę posiadają dużą wartość dla badaczy dawnego Webu.

${ }^{67}$ K. Holub, I. Rudomino, dz. cyt., s. 3-4.

${ }^{68}$ Croatian Web Archive, http://haw.nsk.hr/en (dostęp 26.08.2019).

69 OndareNet, http://www.ondarenet.kultura.ejgv.euskadi.eus:8085/ondarenet/ (dostęp 26.08.2019).

${ }^{70}$ Archived websites (1996 e now), https://trove.nla.gov.au/website (dostęp 26.08. 2019).

${ }^{71}$ WARP Web Archiving Project, http://warp.da.ndl.go.jp/?_lang=en (dostęp 26.08. 2019).

72 Browse DACHS, https://www.zo.uni-heidelberg.de/boa/digital_resources/dachs/ browse_en.html (dostęp 26.08.2019).

${ }_{73}$ Monographics, https://www.padicat.cat/en/search-and-discover/monographics (dostęp 26.08.2019).

74 Thematic harvesting, http://haw.nsk.hr/en/thematic-harvestings (dostęp 26.08. 2019).

${ }^{75}$ Archived Web Sites, https://www.loc.gov/programs/web-archiving/archivedweb-sites/?fa = partof:Digital+Collections\%7Coriginal-format:archived + web + site\&sp =1 (dostęp 26.08.2019).

${ }^{76}$ Topics and Themes, https://www.webarchive.org.uk/en/ukwa/collection (dostęp 26.08.2019).

77 Special Collections, http://eresources.nlb.gov.sg/webarchives/special-collection (dostęp 26.08.2019). 
Udostępnienie odpowiednich dokumentów pozwoliłoby lepiej zrozumieć oraz orientować się w zarchiwizowanym WWW, jednak nie jest to częstą praktyką ${ }^{78}$. Tego rodzaju zasoby nie są ewidencjonowane przy wykorzystaniu pomocy znanych tradycyjnej archiwistyce, takich jak inwentarze, katalogi czy indeksy, a tylko czasami mały wycinek jest katalogowany metodami bibliotecznymi. Zawartość archiwów Webu jest natomiast indeksowana przy użyciu podstawowych metadanych na potrzeby silników wyszukiwawczych, które umożliwiają dotarcie do poszukiwanych materiałów. Niestety funkcjonujące obecnie narzędzia nie spełniają stawianych przed nimi wymagań ${ }^{79}$.

Braki te w znaczącym stopniu utrudniają zrozumienie przebiegu procesu archiwizacji, a w konsekwencji powstałych w ich trakcie zasobów. Trafne wydaje się określenie archiwów Webu mianem „czarnego pudełka” (ang. black box), a więc systemu, którego poszczególne elementy są ukryte przed użytkownikiem lub są trudne do zrozumienia. Jest to skutkiem złożoności przebiegu procesu archiwizacji, szeregu podejmowanych w jego trakcie decyzji oraz czynników ludzkich i technicznych na niego wpływających. W konsekwencji informacje o charakterze proweniencyjnym (m.in. dotyczące przyczyn zachowania konkretnych zasobów) mogą być nieosiągalne, co z kolei może rzutować na późniejszą ich analizę $e^{80}$.

\section{Podsumowanie}

Zawarty w tytule artykułu problem wpływu procesu archiwizacji na zawartość archiwów Webu można rozważać w dwóch jego różnych aspektach, które znacząco wpływają na późniejsze wykorzystanie tych zasobów. Badacz korzystający z zasobów dawnej Sieci powinien być ich świadomy oraz konsekwencji z nich płynących. Zrozumienie ich jest niezbędne dla poprawnej krytyki źródła, jakie mogą stanowić te materiały.

Od strony teoretycznej na archiwalne WWW wpływ ma harvesting, a więc metoda gromadzenia zasobów przy użyciu wyspecjalizowanych robotów internetowych - crawlerów. Na ich funkcjonowanie wpływa wiele ograniczeń - wyni-

78 A. AlSum, M.C. Weigle, M.L. Nelson, H. Van de Sompel, Profiling web archive coverage for top-level domain and content language, „International Journal on Digital Libraries" 2014, t. 14, nr 3-4, 2014, s. 149. DOI: 10.1007/s00799-014-0118-y.

79 M. Costa, M.J. Silva, dz. cyt., s. 442.

80 A. Ben-David, A. Amram, dz. cyt., s. 179-184. 
kających z nich samych oraz od nich niezależnych, w efekcie czego zachowany obraz dawnego Webu nie jest idealny i pełny. Wykonane przez te crawlery archiwalne kopie witryn należy traktować raczej jako fragmentaryczne i niedoskonałe odbitki, na podstawie których można rekonstruować to, co mogło kiedyś istnieć w Sieci. Badacz musi pamiętać, że archiwizacja tego rodzaju zasobów prowadzi do pewnego ich przekształcenia, może pozbawić je pewnych elementów, a więc nie są już one dokładnie tym, czym były wcześniej w „żywej” Sieci.

Z perspektywy praktycznej faktyczna zawartość archiwów WWW jest efektem podejmowanych przez ich organizatorów decyzji związanych z selekcją, a więc ustalaniem, co chcą, a czego nie chcą zachować. Ma to początek już w wyborze zakresu działania projektu, a więc określeniu, jakie materiały będą gromadzone i jaka będzie jego skala. Wśród funkcjonujących inicjatyw możemy znaleźć duże przedsięwzięcia, takie jak Internet Archive lub część archiwów narodowych, a także małe, które dążą do zachowania witryn powiązanych np. z jednym uniwersytetem. Łączy się z tym zróżnicowanie w tematyce gromadzonych zasobów, od najbardziej ogólnej po wysoce sprecyzowaną, przygotowaną dla konkretnych odbiorców. W celu realizacji obranego kierunku poszczególne archiwa korzystają ze strategii gromadzenia masowego i selektywnego. Pierwsza z nich pozwala na gromadzenie dużych ilości danych, jednakże kosztem ich „uporządkowania”, druga natomiast umożliwia większą precyzję, jednak na zdecydowanie mniejszą skalę. Obie strategie mogą się uzupełniać, co widać na przykładzie projektów narodowych.

Archiwa Webu mogą stanowić pewnego rodzaju zagadkę, metaforyczne „czarne pudełko”, które użytkownik musi samodzielnie otworzyć. Wiele informacji pozwalających zrozumieć kontekst powstania zasobów często pozostaje dla niego niedostępne, w związku z czym trudne może być poznanie tego, co dokładnie się w nich znajduje. Mogą mieć one kluczowy wpływ na przeprowadzane badania, ponieważ dotyczą decyzji o tym, co i dlaczego, w jakim zakresie i z jaką częstotliwością postanowiono zarchiwizować. Istotne wydaje się także poinformowanie użytkowników, co mogło nie zostać zachowane. Brak dostępu do tych danych utrudnia dobre rozeznanie się w zasobach archiwów, zwłaszcza że obecnie dostępne narzędzia wyszukiwawcze nie spełniają dostatecznie dobrze swojej roli.

Posługiwanie się przez badacza zasobami dawnego Webu stawia przed nim liczne wyzwania. Na początku powinien zdać sobie sprawę z czynników technologicznych wpływających na proces archiwizacji, a w efekcie na jakość zachowanych zasobów i fakt, że nie są one idealnym odwzorowaniem tego, co kiedyś istniało w Sieci. Następnie powinien wiedzieć, jakich zasobów poszukuje 
i w jakich archiwach może ich poszukiwać, a więc warto, aby był rozeznany wśród inicjatyw funkcjonujących na świecie i w zakresach ich działania. Posiadanie informacji na temat tego, co i dlaczego dane archiwum mogło zarchiwizować bądź nie, może być kluczowe dla przeprowadzanej przez niego kwerendy. Na koniec badacz musi umieć posługiwać się dostępnymi wyszukiwarkami lub posiadać umiejętności pozwalające przygotować własne narzędzia umożliwiające dotarcie do interesujących go materiałów i przeprowadzenie ich analizy.

\section{Bibliografia}

„About DACHS | DACHS | East Asian Library”. Dostęp 26.08.2019. https://www. zo.uni-heidelberg.de/boa/digital_resources/dachs/about_en.html.

AlSum, Ahmed, Michele C. Weigle, Michael L. Nelson, i Herbert Van de Sompel. „Profiling Web Archive Coverage for Top-Level Domain and Content Language". International Journal on Digital Libraries 14, nr 3-4 (sierpień 2014): 149-66. https://doi. org/10.1007/s00799-014-0118-y.

Archive-It. „About Us”. Dostęp 26.08.2019. https://archive-it.org/blog/learn-more/.

Archive-It. „Harvard University Archives”. Dostęp 26.08.2019. https://archive-it.org/ organizations/935.

Archive-It. „MIT Libraries”. Dostęp 26.08.2019. https://archive-it.org/home/MIT.

„Archive Team Collections.” Dostęp 26.08.2019. https://archive.org/details/archiveteam?tab=about.

Ben-David, Anat, i Adam Amram. „The Internet Archive and the Socio-Technical Construction of Historical Facts". Internet Histories 2, nr 1-2 (3 kwiecień 2018): 179-201. https://doi.org/10.1080/24701475.2018.1455412.

Bodleian Libraries. „BEAM: Bodleian Libraries' Web Archive”. Dostęp 26.08.2019. https:// www.bodleian.ox.ac.uk/beam/webarchive.

„Browse DACHS | DACHS | East Asian Library”. Dostęp 26.08.2019. https://www. zo.uni-heidelberg.de/boa/digital_resources/dachs/browse_en.html.

Brügger, Niels. Archiving Websites: general Considerations and Strategies. Aarhus: The Centre for Internet Research, 2005. http://cfi.au.dk/fileadmin/www.cfi.au.dk/publikationer/archiving_underside/archiving.pdf.

Brügger, Niels. „Web Archiving - Between Past, Present, and Future.” W Handbook of Internet Studies, zredagowali Mia Consalvo, Charles Ess, 24-42. Oxford, UK: Wiley-Blackwell, 2011.

Brügger, Niels. „Web Historiography and Internet Studies: Challenges and Perspectives". New Media \& Society 15, nr 5 (sierpień 2013): 752-64. https://doi. org/10.1177/1461444812462852.

Brügger, Niels. „Wenn Das Web Vergangenheit Wird: Web-Geschichtsschreibung, Digitale Geschichte Und Internet-Forschung / When the Present Web Is Later the Past: Web 
Historiography, Digital History and Internet Studies". Historical Social Research 37, No. 4 (2012): 102-117. https://doi.org/10.12759/HSR.37.2012.4.102-117.

Columbia University Libraries. „Web Archives at Columbia.” Dostęp 26.08.2019. https:// library.columbia.edu/collections/web-archives.html.

Common Crawl. „In a Nutshell, Here's Who We Are.” Dostęp 26.08.2019. https://commoncrawl.org/about/.

Costa, Miguel, i Mário J. Silva. „Evaluating Web Archive Search Systems”. W Web Information Systems Engineering - WISE 2012, zredagowali X. Sean Wang, Isabel Cruz, Alex Delis, i Guangyan Huang, 440-454. Berlin, Heidelberg: Springer Berlin Heidelberg, 2012. https://doi.org/10.1007/978-3-642-35063-4_32.

„DACHS - Leiden: The Digital Archive for Chinese Studies, Leiden Division - Homepage”. Dostęp 26.08.2019. https://projects.zo.uni-heidelberg.de/archive2/DACHS_Leiden/.

„End of Term Web Archive: U.S. Government Websites”. Dostęp 26.08.2019. http:// eotarchive.cdlib.org/.

European University Institute. „About the Web Archive of the EU Institutions”. Dostęp 26.08.2019. https://www.eui.eu/Research/HistoricalArchivesOfEU/WebsitesArchivesofEUInstitutions.aspx.

Geereart, Friedel, i Sébastien Soyez. „The first steps towards a Belgian web archive: a federal strategy." Dostęp 26.08.2019. http://netpreserve.org/ga2019/wp-content/ uploads/2019/07/IIPCWAC2019-FRIEDEL_GEERAERT_SEBASTIEN_SOYEZ-The first_steps_towards_a_Belgian_web_archive-a_federal_strategy.pdf.

Holub, Karolina, i Ingeborg Rudomino. "A decade of web archiving in the National and University Library in Zagreb.” Dostęp 26.08.2019. http://library.ifla.org/1092/1/090-holub-en.pdf.

International Organization for Standardization. Information and documentation - Statistics and quality issues for web archiving. ISO/TR 14873. Genewa: ISO, opublikowana 01. 12.2013.

„Internet Archive: About IA”. Dostęp 26.08.2019. https://archive.org/about/.

Keskitalo, Esa-Pekka. Web Archiving in Finland: memorandum for the members of the CDNL. 2010. http://www.doria.fi/bitstream/handle/10024/67051/webarchivingfinland_cdnl.pdf.

Koninklijke Bibliotheek. „Selection.” Dostęp 26.08.2019. https://www.kb.nl/en/organisation/research-expertise/long-term-usability-of-digital-resources/web-archiving/ selection.

Konopa, Bartłomiej. „Archiwa Internetu jako nowe bazy źródłowe”. Archiwa - Kancelarie - Zbiory 9(11) (2018): 49-62. https://doi.org/10.12775/AKZ.2018.003.

Król, Karol. „Z archiwów internetu: zmiany w sposobie prezentacji oferty agroturystycznej." Marketing i Rynek 24, nr 11 (2017): 19-27. http://homeproject.pl/wp-content/ uploads/2018/12/Krol_MiR_11_2017_NR.pdf.

Library of Congress. „Archived Websites | Web Archiving | Programs at the Library of Congress | Library of Congress". Dostęp 26.08.2019. https://www.loc.gov/programs/ web-archiving/archived-websites/. 
Masanès, Julien. „Selection for Web Archives.” W Web Archiving, zredagował Julien Masanès, 71-91. Berlin, Heidelberg: Springer Berlin Heidelberg, 2006.

Masanes, Julien. „Web Archiving Methods and Approaches: A Comparative Study”. Library Trends 54, nr 1 (2005): 72-90. https://doi.org/10.1353/lib.2006.0005.

Milligan, Ian. „Lost in the Infinite Archive: The Promise and Pitfalls of Web Archives”. International Journal of Humanities and Arts Computing 10, nr 1 (marzec 2016): 78-94. https://doi.org/10.3366/ijhac.2016.0161.

Nacionalna i sveučilišna knjižnica u Zagrebu, National and University Library in Zagreb, i University Computing Centre Zagreb Sveučilišni računski centar (Srce). „Hrvatski arhiv weba, HAW.” Dostęp 26.08.2019. http://haw.nsk.hr/en/thematic-harvestings.

Nacionalna i sveučilišna knjižnica u Zagrebu, National and University Library in Zagreb, i University Computing Centre Zagreb Sveučilišni računski centar (Srce). „Thematic harvesting." Dostęp 26.08.2019. http://haw.nsk.hr/en.

National Diet Library. „Archiving Internet Information.” Dostęp 26.08.2019. https:// www.ndl.go.jp/en/collect/internet/index.html.

Netarkivet. „Selektive høstninger.” Dostęp 26.08.2019. http://netarkivet.dk/om-netarkivet/selektive-hostninger_2016/.

Nielsen, Janne. Using Web Archives in Research: an Introduction. Aarhus: NetLab, 2016. http://www.netlab.dk/wp-content/uploads/2016/10/Nielsen_Using_Web_Archives_in_Research.pdf.

„Ondarenet”. Dostęp 26.08.2019. http://www.ondarenet.kultura.ejgv.euskadi.eus:8085/ ondarenet/.

Pamuła-Cieślak, Natalia. „Ukryty Internet - nowe podejście.” W Oblicza przestrzeni informacyjnej $w$ dobie Web 2.0, zredagowali Katarzyna Domańska, Ewa Głowacka i Paweł Marzec, 35-48. Bydgoszcz: Wydawnictwo Uniwersytetu Kazimierza Wielkiego, 2016.

Pedicat. „Mission and objectives.” Dostęp 26.08.2019. https://www.padicat.cat/en/ about-us/what-padicat/mission-and-objectives.

Pedicat. „Monographics.” Dostęp 26.08.2019. https://www.padicat.cat/en/search-anddiscover/monographics.

Schostag, Sabine, i Eva Fønss-Jørgensen. "Webarchiving: Legal deposit of internet in Denmark: a curatorial perspective." Microform \& Digitization Review 41, nr 3-4 (2012): 110-120.

Spaniol, Marc, Dimitar Denev, Arturas Mazeika, Gerhard Weikum, i Pierre Senellart. „Data Quality in Web Archiving”. W WICOW '09 Proceedings of the 3rd workshop on Information credibility on the web, 19-26. Nowy Jork: ACM Press, 2009. https://doi. org/10.1145/1526993.1526999.

Summers, Ed, i Ricardo Punzalan. „Bots, Seeds and People: Web Archives as Infrastructure". W Proceedings of the 2017 ACM Conference on Computer Supported Cooperative Work and Social Computing - CSCW'17, 821-834. Portland, Oregon, USA: ACM Press, 2017. https://doi.org/10.1145/2998181.2998345.

The British Library. „UK Web Archive”. Dostęp 26.08.2019. https://www.bl.uk/collection-guides/uk-web-archive. 
The National Archives. „UK Government Web Archive”. Dostęp 26.08.2019. http://www. nationalarchives.gov.uk/webarchive/.

The National Archives, Washington D.C. „Congressional \& Federal Government Web Harvests.” Dostęp 26.08.2019. https://www.webharvest.gov/.

Thouvenin, Florent, Peter Hettich, Herbert Burkert, i Urs Gasser. Remembering and Forgetting in the Digital Age. T. 38. Law, Governance and Technology Series. Cham: Springer International Publishing, 2018. https://doi.org/10.1007/978-3-319-90230-2.

Trove. „Australian Web Archive.” Dostęp 26.08.2019. https://trove.nla.gov.au/website.

UK Web Archives. „Topics and Themes.” Dostęp 26.08.2019. https://www.webarchive. org.uk/en/ukwa/collection.

UNT Libraries. „CyberCemetery Home.” Dostęp 26.08.2019. https://govinfo.library. unt.edu/.

Vernalte, Francisca P. , i Sonia M. Maciá. „Capturing the Basque Web.” Dostęp 26.08.2019. http://eprints.rclis.org/13164/1/EN_Lida_paper_Ondarenet_APA.pdf.

Web Archive Singapore. „Frequently asked questions.” Dostęp 26.08.2019. http://eresources.nlb.gov.sg/webarchives/faq.

Web Archive Singapore. „Special collections.” Dostęp 26.08.2019. http://eresources.nlb. gov.sg/webarchives/special-collection.

„Web Archiving Project (WARP)”. Dostęp 26.08.2019. http://warp.da.ndl.go.jp/?_ lang=en.

„Wikimedia Foundation Collections.” Dostęp 26.08.2019. https://archive.org/details/ wikimediadownloads $\mathrm{tab}=$ collection. 
